\title{
URINE CATECHOLAMINE EXCRETION AFTER LARGE DOSES OF FENTANYL, FENTANYL AND DIAZEPAM AND FENTANYL, DIAZEPAM AND PANCURONIUM
}

\author{
Wen-Shin Liu, Arun V. Bidwai, Judd K. Lunn, and Theodore H. Stanley
}

LARGE DOSES OF FENTANYL $(0.01-0.5 \mathrm{mg} / \mathrm{kg})$ with diazepam and pancuronium have little effect on cardiovascular dynamics and have been suggested as an alternative to morphine anaesthesia in critically ill patients. ${ }^{1}$ Cardiovascular stability during and after morphine anaesthesia has been attributed to endogenous catecholamine release. $^{2-4}$ The influence of large doses of fentanyl and fentanyl with diazepam and pancuronium on catecholamine release is unknown. This study investigated the effects of fentanyl, fentanyl with diazepam and fentanyl with diazepam and pancuronium on urine epinephrine and norepinephrine excretion rates in dogs.

\section{METHODS}

Nine fasted, mongrel dogs with an average weight of $13.9 \mathrm{~kg}$ served as the experimental animals. Each was premedicated with atropine $0.5 \mathrm{mg} / 10 \mathrm{~kg}$ intramuscularly one hour before anaesthesia and had an intravenous infusion of lactated Ringer's solution ( $20 \mathrm{ml} / \mathrm{kg} /$ hour $)$ started in a foreleg immediately before induction. Following this, sodium thiopentone $25 \mathrm{mg} / \mathrm{kg}$ and then succinylcholine 2 $\mathrm{mg} / \mathrm{kg}$ were administered intravenously, the trachea was intubated and the lungs ventilated with 100 per cent oxygen at a tidal volume of 5 to $12 \mathrm{ml} / \mathrm{kg}$ with a volume limited respirator. Minute respiratory volume was adjusted as necessary to maintain $\mathrm{Pa}_{\mathrm{CO}_{2}}$ between $30-35$ torr $(4-4.6 \mathrm{kPa})$ as measured in aortic blood every 15 to 30 minutes.

Catheters were placed in the urinary bladder, a jugular vein and, through a small groin incision, in a femoral artery. The latter was threaded 20 to $35 \mathrm{~cm}$ into the central aorta. The aortic pressure catheter was connected through a Statham $\mathrm{P}_{23} \mathrm{Db}$ arterial pressure transducer to a central digital computer substation in the laboratory. After appropriate dye dilution calibration, cardiac output $\left(\dot{Q}_{\mathrm{T}}^{\mathrm{T}}\right\rangle$, mean aortic blood pressure $(\overline{\mathrm{BP}})$ and heart rate $(\mathrm{HR})$ were determined by the method of Warner, Gardner and Toronto. ${ }^{5}$

Following completion of preparatory procedures the bladder was emptied and urine collected during a 30-minute control period. At the end of this period $\dot{Q} \mathbf{T}$, $\overline{\mathrm{BP}}$ and $\mathrm{HR}$ were measured and fentanyl $0.5 \mathrm{mg} / \mathrm{kg}$ was administered intravenously at a rate of 0.2 to $0.3 \mathrm{mg} /$ minute. Urine was collected during fentanyl infusion and $\dot{\mathrm{Q}} \mathrm{T}, \overline{\mathrm{BP}}$ and $\mathrm{HR}$ were remeasured at its conclusion. Following this

From the Department of Anesthesiology, the University of Utah College of Medicine, 50 North Medical Drive, Salt Lake City, Utah, 84132.

Presented in part at the 1976 annual meeting of the American Society of Anesthesiologists in San Francisco, California, October 1976. 
$1 \mathrm{mg} / \mathrm{kg}$ of diazepam was administered intravenously, urine was collected for another 30 minutes and cardiovascular dynamics were measured at the end of the collection period. Pancuronium $0.1 \mathrm{mg} / \mathrm{kg}$ was then given rapidly intravenously and the collecting and measuring procedures were repeated.

Urine specimens were collected in amber-coloured glass containers with sufficient $0.1 \mathrm{~N}$ perchloric acid added to maintain $\mathrm{pH}$ between 2 and 3. Each specimen was frozen until time of analysis. Collected urine was analyzed for epinephrine and norepinephrine by the automated fluorometric method of Viktora, Baukal and Wolff. ${ }^{6}$

Data were analyzed for statistical significance using Student's paired t-test.

\section{Results}

Fentanyl did not significantly change $\dot{\mathrm{Q}} \mathrm{T}$ or $\overline{\mathrm{B}} \overline{\mathrm{P}}$, but did reduce $\mathrm{HR}$ and urine flow rate $(P<0.05)$ (Figures $1-4)$. Urine epinephrine and norepinephrine excretion rates were significantly increased by fentanyl $(\mathrm{P}<0.05)$ (Figures 5 and 6 ). Diazepam caused no significant further changes in $\dot{\mathrm{Q}} \mathrm{T}, \overrightarrow{\mathrm{BP}}$ or $\mathrm{HR} 30$ minutes after

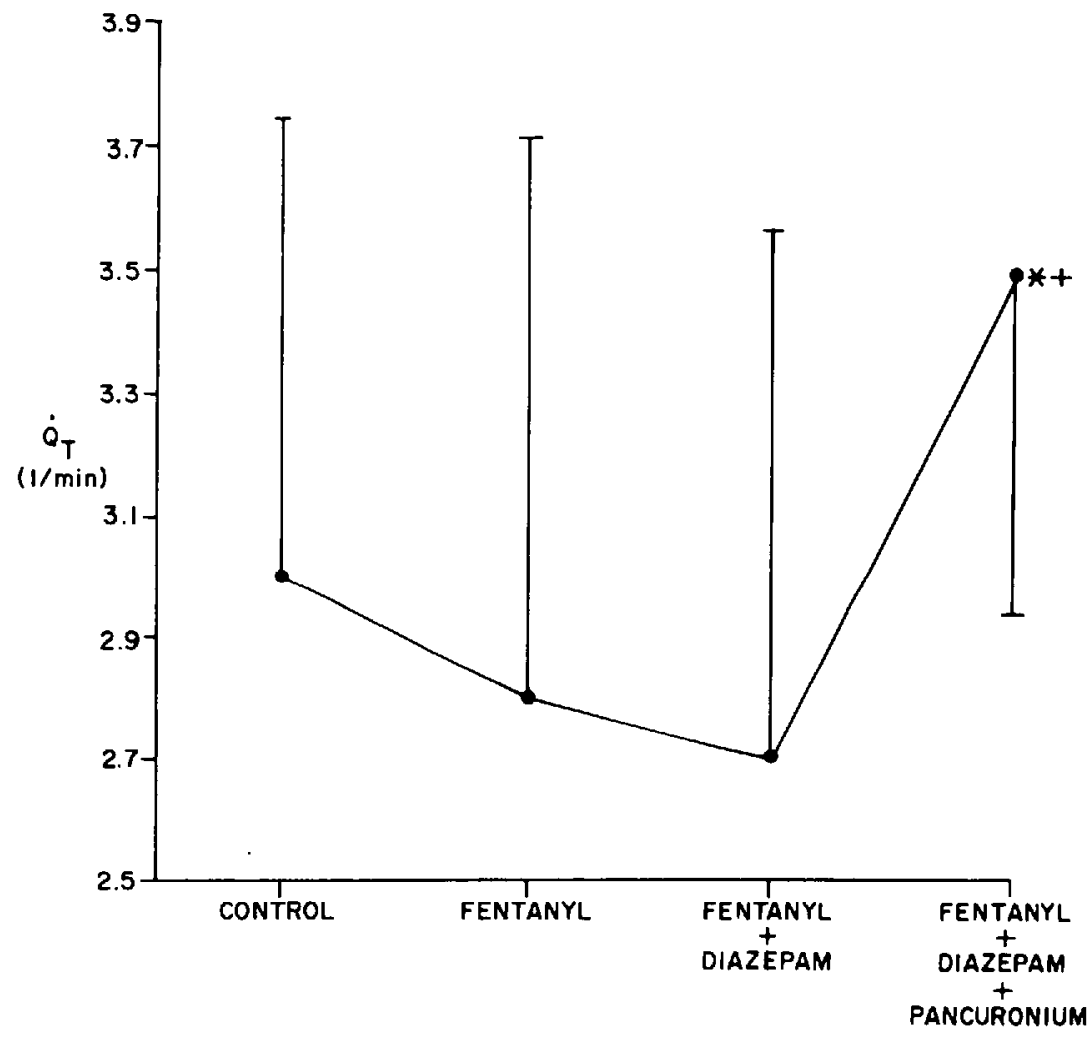

Figure 1. Cardiac output (mean \pm SD) following fentanyl, fentanyl and diazepam, and fentanyl, diazepam and pancuronium. ${ }^{\circ} \mathrm{P}<0.05$, students paired t-test when compared to control values. $+\mathrm{P}<0.025$, students paired t-test when compared to fentanyl and diazepam values. 


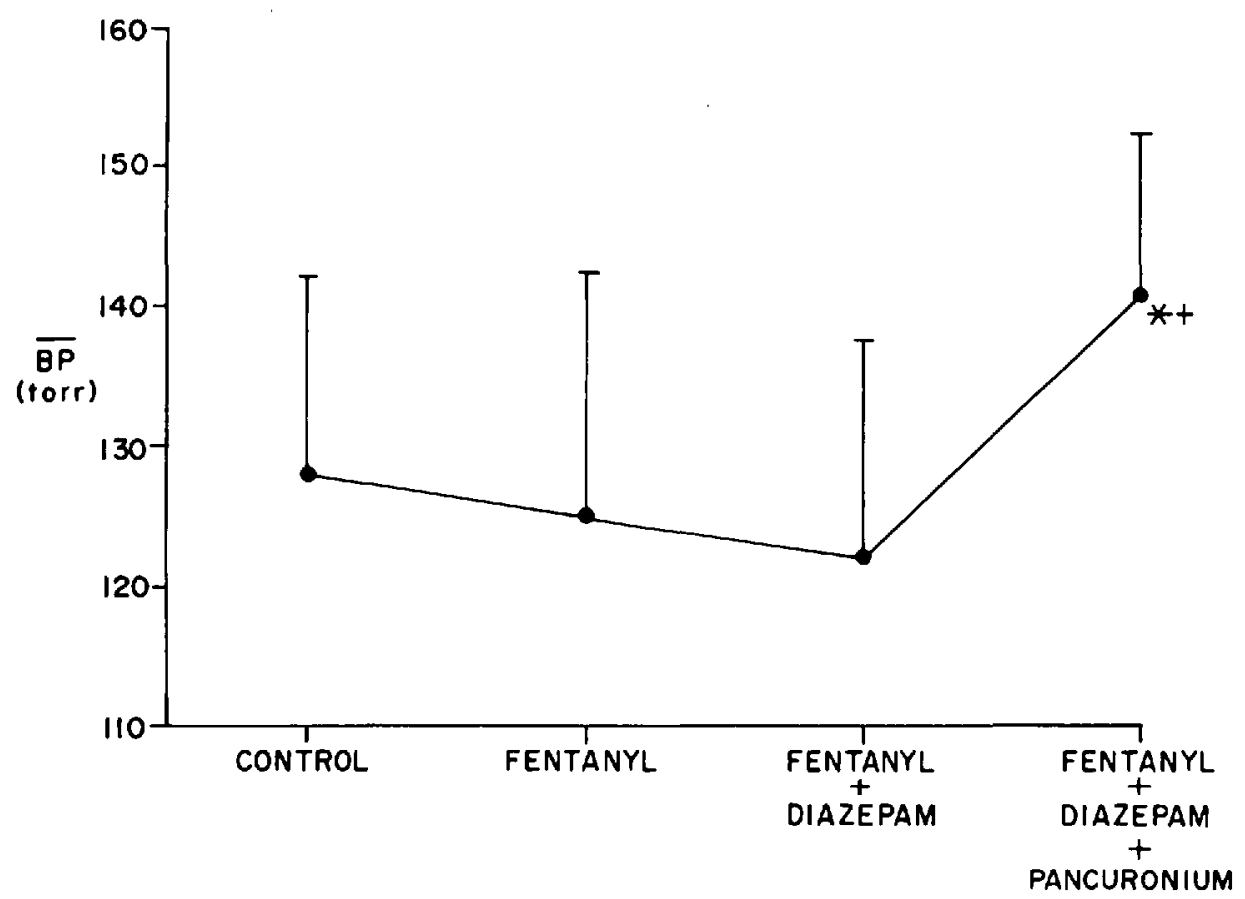

Ficure 2. Mean aortic blood pressure (mean \pm SD) following fentanyl, fentanyl and diazepam, and fentanyl, diazepam and pancuronium. Symbols are the same as in Figure 1.

administration, but urine epinephrine and norepinephrine excretion rates were reduced to control (pre-fentanyl) levels. Addition of pancuronium after fentanyl and diazepam increased urine flow rate to pre-fentanyl levels and elevated $\dot{Q} \mathrm{~T}$, $\overline{\mathrm{BP}}$ and $\mathrm{HR}$ above controls but produced no significant change in urine epinephrine or norepinephrine excretion.

\section{Discussion}

The results of this study show that fentanyl increases urinary catecholamine excretion. Since urinary epinephrine and norepinephrine excretion parallel blood levels of the amines ${ }^{\bar{T}}$ our findings suggest that fentanyl increases catecholamine blood levels. In addition, the data demonstrate that urinary epinephrine and norepinephrine excretion remain elevated for only a short time following fentanyl administartion, suggesting that the fentanyl effect on circulating catecholamines is only transient or that it is antagonized by diazepam. Finally, our results indicate that cardiovascular stimulation after administration of pancuronium to dogs anaesthetized with fentanyl and diazepam is not associated with increased endogenous catecholamine excretion.

Experiments in dogs have shown that large doses of morphine stimulate. endogenous catecholamine release and the latter increase myocardial inotropy. ${ }^{8}$ In a recent report Stanley, Isern-Amaral and Lathrop ${ }^{3}$ have demonstrated that 


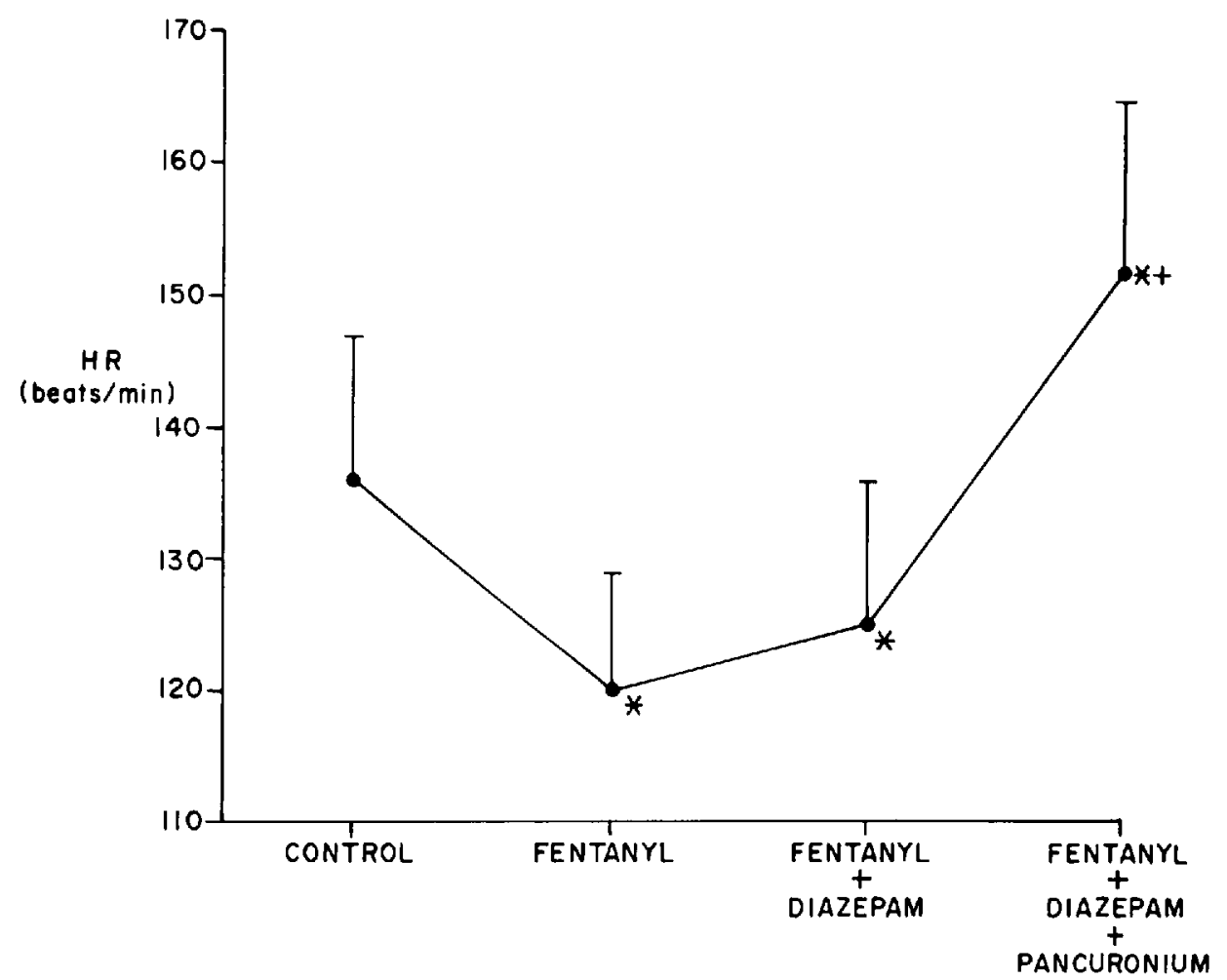

Ficune 3. Heart rate (mean \pm SD) following fentanyl, fentanyl and diazepam, and fentanyl, diazepam and pancuronium. Symbols are the same as in Figure 1.

morphine increases urine norepinephrine excretion in patients with valvular heart disease and suggested that associated elevations in plasma catecholamine levels might explain the remarkable cardiovascular stability observed with this technique in critically ill patients. In a subsequent study" we found that large $(0.5 \mathrm{mg} / \mathrm{kg})$ and even enormous $(2 \mathrm{mg} / \mathrm{kg}$ ) doses of fentanyl did not markedly alter cardiovascular dynamics in the dog. On the basis of these results we indicated that large doses of fentanyl might be an attractive alternative to morphine anaesthesia in critically ill patients. Our findings in this study suggest that cardiovascular stability after fentanyl could, as after morphine, be related to increased circulating levels of epinephrine, norepinephrine or both. A recent report by Freye ${ }^{10}$ provides additional support for this mechanism. He showed that intravenous fentanyl in doses up to $0.03 \mathrm{mg} / \mathrm{kg}$ increases canine myocardial contractility in a dose-related fashion as measured by LV dp/dt max. ${ }^{*}$ Interestingly, Freye found that higher doses of fentanyl $(0.03$ to $0.10 \mathrm{mg} / \mathrm{kg})$ did not further increase contractility. Indeed, $\mathrm{LV} \mathrm{dp} / \mathrm{dt}$ max returned to control values with fentanyl doses in excess of $0.03 \mathrm{mg} / \mathrm{kg}$. It is possible that increased excretion of epinephrine and norepinephrine also occurred only after administration of low doses of fentanyl in this

- Maximum rate of change of left ventricular pressure development as a function of time. 


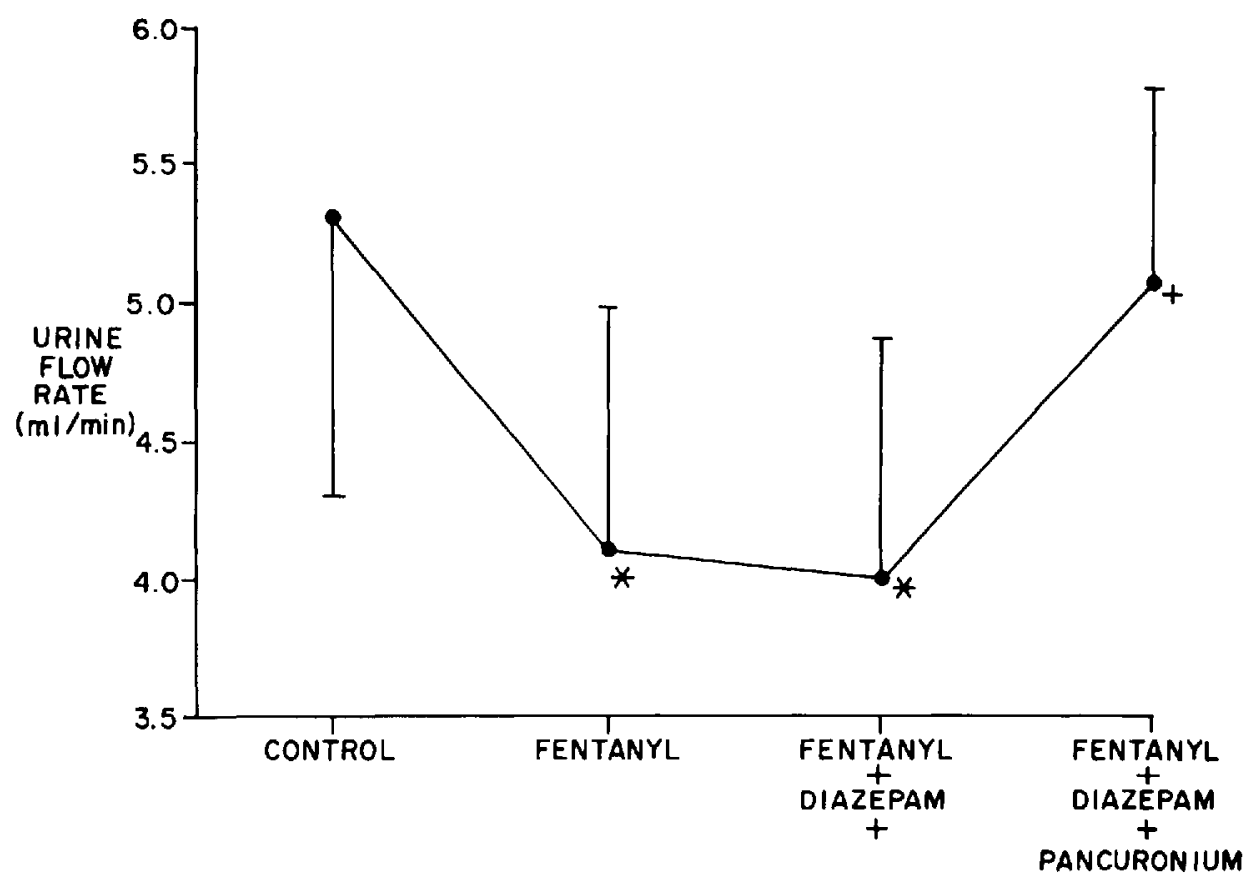

FIcure 4. Urine flow rate (mean \pm SD) following fentanyl, fentanyl and diazepam, and fentanyl, diazepan and pancuronium. Symbols are the same as in Figure 1.

study. Unfortunately, our protocol did not allow for separation of the effects of high and low doses of fentanyl on catecholamine excretion. However, if low doses of fentanyl stimulate endogenous catecholamine release and high doses of the drug have no influence on catecholamine blood levels the catecholamine response to fentanyl would appear to be similar to that following morphine administration. Recent reports from this laboratory ${ }^{2-4}$ have shown that while patients receiving an average of $1.7-2.5 \mathrm{mg} / \mathrm{kg}$ of morphine have an immediate elevation in urine norepinephrine excretion patients getting an average of $3.5 \mathrm{mg} / \mathrm{kg}$ of the compound experience no change in urine norepinephrine excretion until over one hour later. They suggested that high blood levels of morphine may have no influence or inhibit while lower blood levels may stimulate endogenous catecholamine release. Our data in this study are not incompatible with a similar mechanism following fentanyl administration.

Diazepam has little effect on cardiovascular dynamics in unanaesthetized patients with cardiac disease and has, as a result, been advocated as a sedative and induction agent for patients with little cardiac reserve. ${ }^{11}$ The influence of diazepam on catecholamine blood levels or urine excretion has not, to our knowledge, been investigated during administration of the drug by itself or following its use as a supplement. Diazepam increases myocardial contractility in dogs but the mechanism is unknown. ${ }^{12}$ Our data suggest that diazepam does not increase catecholamine blood levels, at least not after large doses of fentanyl.

Increases in blood pressure and pulse rate are considered advantages of pan- 


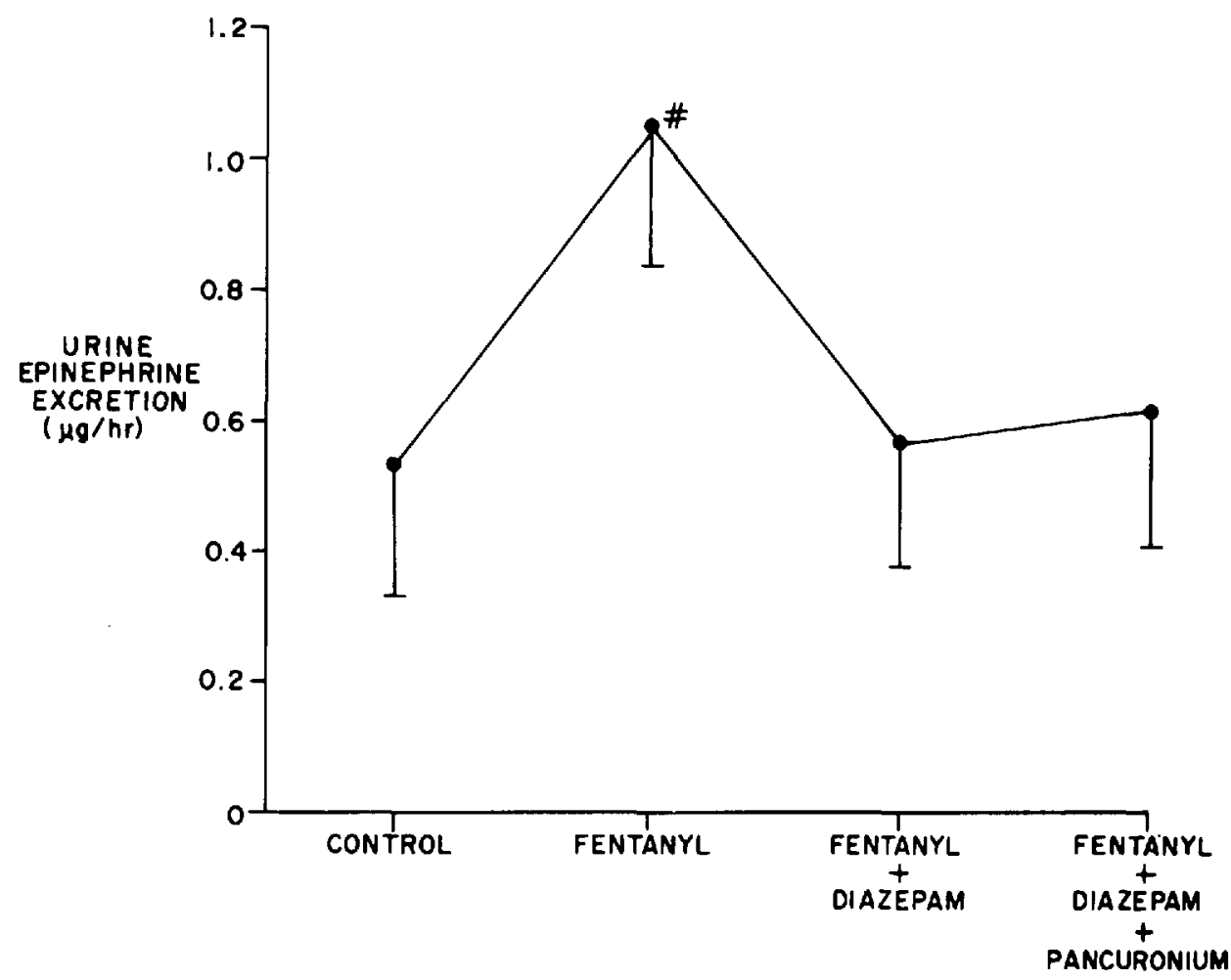

Ficune 5. Urine epinephrine excretion rate (mean \pm SD) following fentanyl, fentanyl and diazepam, and fentanyl, diazepam and pancuronium. \#P $<0.025$, students paired t-test when compared to control values.

curonium over d-tubocurarine and have resulted in the recent increased popularity of this muscle relaxant. ${ }^{13}$ Stoelting ${ }^{13}$ found that pancuronium $0.08 \mathrm{mg} / \mathrm{kg}$ significantly increases heart rate, cardiac output and arterial blood pressure in man during halothane anaesthesia. Pancuronium produced even greater increases in all these variables in this study. It has been suggested, on the basis of smaller increases in heart rate after premedication with atropine than before, that the cardiac stimulating properties of pancuronium are primarily related to cardiac vagal inhibition. ${ }^{14}$ On the other hand, pancuronium has been shown to increase urinary catecholamines in unanaesthetized patients with tetanus. ${ }^{15}$ There are, however, no other reports of increased blood or urine catecholamine concentrations following its administration. Furthermore, two recent studies by Bonta ${ }^{16}$ and by Saxema and Bonta ${ }^{17}$ support cardiac vagal inhibition as the mechanism of cardiac stimulation by pancuronium. These authors showed that $0.05 \mathrm{mg} / \mathrm{kg}$ of the compound completely and selectively blocks cardiac muscarinic cholinergic receptors to vagal stimulation as well as to stimulation by acetylcholine, carbamylcholine and methacholine. Absence of changes in catecholamine excretion with simultaneous increases in heart rate and cardiac output in this study are consistent with a cardiac vagal inhibiting action of pancuronium after large doses of fentanyl and diazepam. 


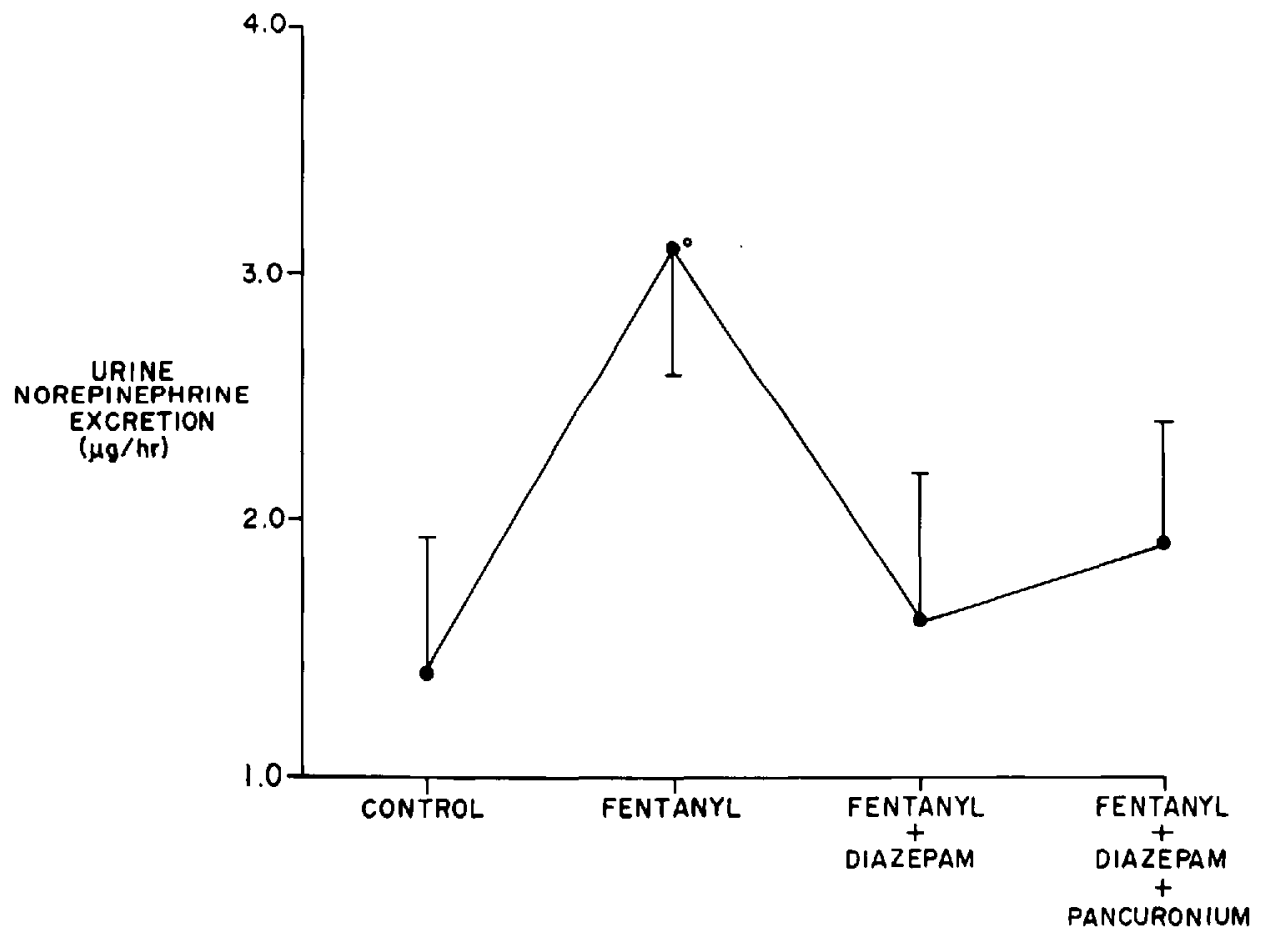

FIgURE 6. Urine norepinephrine excretion rate (mean \pm SD) following fentanyl, fentanyl and diazepam, and fentanyl, diazepam and pancuronium. ${ }^{\circ} \mathrm{P}<0.01$, students paired t-test when compared to control values.

\section{SUMMARY}

The effects of fentanyl $(0.5 \mathrm{mg} / \mathrm{kg}$ iv $)$, fentanyl with diazepam ( $1 \mathrm{mg} / \mathrm{kg}$ iv) and fentanyl, diazepam and pancuronium $(0.1 \mathrm{mg} / \mathrm{kg}$ iv $)$ on heart rate (HR), mean arterial blood pressure $(\overline{\mathrm{BP}})$, cardiac output $(\dot{\mathrm{Q} T})$, urine flow rate and urine epinephrine and norepinephrine excretion were determined in nine dogs. Fentanyl did not significantly change $\dot{Q} \mathrm{~T}$ or $\overline{\mathrm{BP}}$ but did reduce $\mathrm{HR}$ and urine flow rate (P $<0.05)$. Urine epinephrine and norepinephrine excretion rates were significantly increased by fentanyl $(\mathrm{P}<0.05)$. Diazepam caused no significant further changes in $\dot{\mathrm{Q}} \mathrm{T}, \overline{\mathrm{BP}}$ or $\mathrm{HR} 30$ minutes after administration, but urine epinephrine and norepinephrine excretion rates were reduced to control (pre-fentanyl) levels. Addition of pancuronium after fentanyl and diazepam increased urine flow rate to prefentanyl levels and elevated $\mathrm{QT}, \overline{\mathrm{BP}}$ and $\mathrm{HR}$ above controls but produced no significant change in urine epinephrine or norepinephrine excretion. These data suggest that fentanyl increases catecholamine blood levels and imply that the latter may be one mechanism by which cardiovascular dynamics are maintained stable during fentanyl anaesthesia. Our findings also demonstrate that cardiovascular stimulation after pancuronium is not associated with increased urinary catecholamine excretion. 


\section{RÉSUMÉ}

Le Fentanyl à forte dose, associé au Diazepam et au Pancuronium, affecte peu la dynamique cardio-vasculaire et, pour cette raison, cette association a été suggérée chez les grands malades. On ne connait pas l'influence de cette technique sur les taux sanguin et urinaire de catécholamines.

Nous avons donc étudié les effets du Fentanyl ( $0.5 \mathrm{mg} / \mathrm{kilo}$ i.v. ), du Fentanyl associé au Diazepan ( $1 \mathrm{mg} /$ kilo i.v.), et de l'addition de Pancuronium $(0.1 \mathrm{mg} / \mathrm{kilo}$ i.v.) aux deux autres, ceci chez neuf chiens, L'on a également déterminé les variations de la fréquence cardiaque, de la pression artérielle moyenne, et le débit cardiaque.

Le Fentanyl n'a pas modifié significativement la pression moyenne, ni le débit cardiaque, mais il a diminué $(p<0.5)$ la fréquence cardiaque et le débit urinaire. Les taux d'Epinéphrine et de Norépinéphrine urinaires ont été significativement élevés $(\mathrm{p}<0.05)$ par le Fentanyl.

Trente minutes après son administration, l'addition de Diazepam n'avait pas modifié la fréquence, la pression moyenne et le débit cardiaque, mais les taux d'excrétion urinaire d'Epinéphrine et de Norépinéphrine étaient redescendus aux niveaux observés avant l'administration de Fentanyl. Enfin, laddition de Pancuronium à la suite du Fentanyl et du Diazepam augmentait le débit urinaire aux chiffres observés avant l'administration de Fentanyl, élevait la pression moyenne, la fréquence et le débit cardiaques, mais n'amenait pas de modification dans l'excrétion urinaire d'Epinéphrine et de Norépinéphrine.

\section{REFERENCES}

1. Liu, W.S., Bidwai, A.V., Stanley, T.H., Loeser, E.A., \& Bidwai, V. The cardiovascular effects of diazepan and of diazepam and pancuronium during fentanyl and oxygen anesthesia. Canad. Anaesth. Soc. J. 23: 395 (1976).

2. Stanley, T.H., Isern-Amaral, J., \& Lathrop, G.D. The effects of morphine and halothane anesthesia on urine norepinephrine during and after coronary artery surgery. Canad. Anaesth. Soc. J. 22: 478 (1975).

3. Stanley, T.H., Isemi-Amaral, J., \& Lathrop, G.D. Urine norepinephrine excretion in patients undergoing mitral or aortic valve replacement with morphine anesthesia. Anesth. \& Analg. 54; 509 (1975).

4. Stanley, T.H., Isern-Amaral, J., \& Lathrop, G.D. The effects of morphine and halothane anaesthesia on urine norepinephrine during surgery for congenital heart disease. Canad. Anaesth. Soc. J. 23: 58 (1976).

5. Warner, H.R., Gardner, F.M., \& Toronto, A.R. Computer-based monitoring of cardiovascular functions in post-operative patients. Circulation 38: 68 (1968).

6. Viktora, J.K., Baukal, A., \& WolfF, F.W. New automated flurometric methods for estimation of small amounts of adrenaline and noradrenaline. Anal. Biochem. 28: 513 (1968).

7. Axton, A.H., Gravesstein, J.S., \& Wheat, M.W. Extracorporeal circulation and endogenous epinephrine and norepinephrine in plasma, atrium and urine in man. Anesthesjology 25: $262(1964)$.

8. Vasko, J.S., Henney, R.P., Brawley, R.K., Oldham, H.N., \& Morrow, A.G. Effects of morphine on ventricular function and myocardial contractile force. Amer. J. Physiol. 210: 329-334 (1966).

9. Liv, W.S., BidwaI, A.V., Stanley, T.H., \& Isenn-Amanal, J. Cardiovascular dynamics after large doses of fentanyl and fentanyl plus $\mathrm{N}_{2} \mathrm{O}$ in the dog. Anesth. \& Analg. 55: 168 (1976).

10. Freye, E. Cardiovascular effects of high doses of fentanyl, meperidine and naloxone in dogs. Anesth. \& Analg. 53: 40 (1974). 
11. Dalen, J.E., Evans, G.L., Banas, J.S., Bhooks, H.L., Paraskos, J.A., \& Dexter, L. The hemodynamic and respiratory effects of diazepam (valium). Anesthesiology 30:259 (1969).

12. Prinde, K.H., Gold, H.K., Cardon, P.V., \& Epstein, S.E. Effects of psychopharmacologic agents on myocardial contractility. J. Pharmacol. Exp. Ther. 173: 133 (1970).

13. Stoelting, R.K. The hemodynamic effects of pancuronium and d-tubocurarine in anesthetized patients. Anesthesiology 36: 612 (1972).

14. Kelman, G.R. \& Kennedy, B.R. Cardiovascular effects of pancuronium in man. Brit. J. Anaesth. 43: 335 (1971).

15. Clough, C. \& Dykes, J.R.W. Assay of urinary catecholamines in patients treated with muscle relaxant drugs. Brit. J. Anaesth, 45: 617 (1973).

16. BonTA, I.L. Pharmacological interaction between pancuronium bromide and anaesthetics. Eur. J. Pharmacol. 4: 83 (1968).

17. SAXENA, P.R. \& BontA, I.L. Specific blockade of cardiac muscarinic receptors by pancuronium bromide. Arch. Int. Pharmacodyn. 189: 410 (1971). 